\title{
UTILIZAÇÃO DOS MÉTODOS ELETRORESISTIVIDADE E POLARIZAÇÃO INDUZIDA COM AQUISIÇÃO DE DADOS 3D PARA CARACTERIZAÇÃO GEOAMBIENTAL DE UMA ÁREA À JUSANTE DO ATERRO DE RESÍDUOS SÓLIDOS URBANOS DE BAURU - SP
}

\author{
Andréa Teixeira Ustra \\ Orientador: Dr. Vagner Roberto Elis (IAG/USP) \\ 205 p. - Dissertação (Mestrado) - Defesa 28.03.2008
}

\begin{abstract}
RESUMO. Uma área contaminada à jusante do Aterro de resíduos sólidos urbanos de Bauru foi investigada através dos métodos Eletroresistividade e Polarização Induzida, com uma técnica de imageamento 3D. A área investigada foi escolhida com base em resultados precedentes de investigações geofísicas e análises químicas das águas de poços de monitoramento, que indicam a ocorrência de contaminação incipiente. 0 objetivo do levantamento foi detectar e delinear a pluma de contaminação produzida pelos resíduos e adquirir informações detalhadas sobre a área afetada. 0 conjunto de dados 3D foi formado por dados de uma série de caminhamentos elétricos paralelos realizados com o arranjo dipolo-dipolo, e foi invertido como um levantamento 3D. Essa técnica de aquisição é menos trabalhosa do que um levantamento 3D completo e ainda assim o modelo resultante deve fornecer os maiores contrastes de resistividade e permitir uma visão tridimensional das principais feições. Modelos sintéticos 2D de resistividade foram construídos com o objetivo de analisar a qualidade dos dados e consequentemente do modelo 3D gerado. Os resultados dos modelos invertidos de resistividade e cargabilidade (inversão 3D) sugerem a presença de uma pluma contaminação e seu caminho preferencial, que segue o sentido do fluxo subterrâneo. Dados de análises químicas das águas de poços de monitoramento comprovam a contaminação incipiente. Modelos quasi 3D de resistividade e cargabilidade foram construídos, com diferentes distâncias entre as linhas de levantamento. Esses modelos identificaram os maiores contrastes observados nos modelos 3D, entretanto criaram diversos artefatos que dificultaram a interpretação. Um modelo sintético 3D de resistividade foi construído e as inversões dos dados obtidos pela simulação de um levantamento diagonal cruzado com arranjo pólo-polo e um levantamento em linhas paralelas com arranjo dipolo-dipolo mostram que as duas aquisições fornecem resultados muito semelhantes. A técnica de aquisição 3D utilizada nesse trabalho mostrou-se eficiente no mapeamento da pluma de contaminação em estudos de áreas de disposição de resíduos e deve ser considerada na escolha da técnica de aquisição para o estudo de áreas complexas.
\end{abstract}

ABSTRACT. Contaminated site downstream a landfill in Brazil was investigated using a 3D resistivity and induced polarization imaging technique. The choice of the investigated area was based on previous geophysical investigations and chemical analysis data from the monitoring wells that indicate the occurrence of incipient contamination. The purpose of this investigation was to detect and delineate the contamination plume produced by the wastes and to obtain detailed information about the affected area. The data set consisted of a series of parallel electrical profile data acquired with the dipole-dipole array, and was inverted as a 3D survey. This acquisition technique is less troublesome than a complete 3D survey, and still the resulting model should provide the major resistivity contrasts and enables a tridimensional picture of the main features. 2D synthetic models were constructed to evaluate the data quality and hence the $3 \mathrm{D}$ generated model quality. The results suggest the presence of a contamination plume and their preferential path, which is in good agreement with the underground water flow data. Chemical analysis data from the monitoring wells confirm the incipient contamination. Quasi 3D resistivity and chargeability models were constructed, with different spacing between the survey lines. These models identified the major contrasts observed in the 3D models; however they created artifacts that can mislead the interpretation. A 3D synthetic model was constructed and their inversion obtained simulating a cross-diagonal survey with pole-pole array and a parallel line survey with dipole-dipole array yielded very similar results. The 3D technique reveals to be efficient in waste disposal sites investigations, and should be taken into account when choosing the investigation technique in complex sites. 